\title{
Pengaruh Motivasi Pada Minat Mahasiswa Non Akuntansi Program Reguler Mengikuti Pendidikan Profesi Akuntansi
}

\author{
Aven Maria Jeniari' \\ Fakultas Ekonomi dan Bisnis \\ Universitas Udayana, Indonesia. \\ Email: avenmaria1234@gmail.com
}

\author{
I.G.A.M Asri Dwija Putri² \\ Fakultas Ekonomi dan Bisnis \\ Universitas Udayana, Indonesia.
}

\begin{abstract}
ABSTRAK
Penelitian ini bertujuan untuk mengetahui pengaruh motivasi sosial, motivasi karir, motivasi kualitas, motivasi ekonomi dan motivasi gelar terhadap minat mahasiswa non akuntansi untuk mengikuti program pendidikan profesi akuntansi (PPAk). Penelitian ini dilakukan di Fakultas Ekonomi dan Bisnis Universitas Udayana pada mahasiswa non akuntansi S1 program reguler angkatan 2016, dengan menggunakan teknik kuesioner sebagai pengumpulan data.Jumlah responden dalam penelitian ini sebanyak 169 orang. Teknik analisis yang digunakan yaitu teknik analisis linear berganda. Berdasarkan hasil analisis penelitian diketahui bahwa motivasi sosial, motivasi karir, motivasi gelar, motivasi ekonomi, dan motivasi kualitas berpengaruh pada minat mahasiswa non akuntansi untuk mengikuti Pendidikan Profesi Akuntansi.Hal ini menujukkan bahwa mahasiswa non akuntansi beranggapan bahwa Pendidikan Profesi akuntansi merupakan pendidikan yang dapat meningkatkan pengetahuan.
\end{abstract}

Kata Kunci Motivasi sosial, Motivasi karir, Motivasi gelar, Motivasi ekonomi, Motivasi kualitas, Minat mengikuti PPAk.

\section{The Effect of Motivation on Non-Accounting Students Interest Regular Program Following Accounting Professional Education}

\begin{abstract}
This study aims to determine the effect of social motivation, career motivation, quality motivation, economic motivation and degree motivation on the interest of non accounting students to take part in the accounting profession education program (PPAk). This research was conducted at the Faculty of Economics and Business, Udayana University, in the non-accounting $S 1$ regular program students, using questionnaire techniques as data collection. The number of respondents in this study was 169 people. The analysis technique used is multiple linear analysis techniques. Based on the results of the research analysis, it is known that social motivation, career motivation, degree motivation, economic motivation, and quality motivation influence the interest of non accounting students to take part in Accounting Professional Education. Knowledge .
\end{abstract}

Keywords : Social motivation, career motivation, degree motivation, economic motivation, quality motivation, interest in joining PPAk.

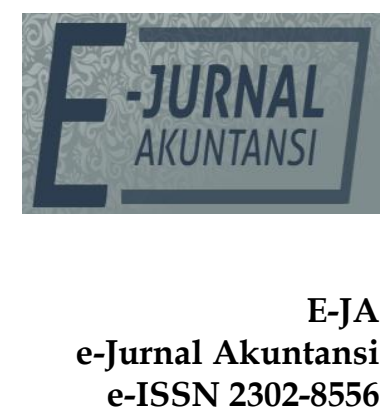

Denpasar, Vol. 28 No. 3

September 2019

Hal. 1732-1748

Artikel masuk: 12 April 2019

Tanggal diterima: 16 Mei 2019 


\section{PENDAHULUAN}

Pendidikan Profesi Akuntansi (PPAk) merupakan jenjang pendidikan tambahan yang ditujukan bagi seorang lulusan Sarjana Ekonomi jurusan akuntansi yang ingin mendapatkan gelar akuntan. Sebelum ditetapkannya Surat Keputusan Menteri Pendidikan Nasional No.179/U/2001 tentang penyelenggaraan Pendidikan Profesi Akuntansi (PPAk), pemberian gelar akuntan di Indonesia didasarkan pada Undang-Undang No. 34 Tahun 1954 yang menyatakan bahwa gelar akuntan diberikan kepada lulusan Perguruan Tinggi Negeri yang ditunjuk pemerintah atau Perguruan Tinggi Universitas Udayana yang memenuhi syarat untuk menghasilkan akuntan atas proses pendidikannya.

Adapun syarat-syarat mengikuti Pendidikan Profesi Akuntansi (PPAk), sesuai dengan PMK Nomor 25/PMK.01/2014 Pasal 3 ayat (3), untuk mengikuti Pendidikan Profesi Akuntansi (PPAk), seseorang harus berpendidikan paling rendah diploma empat (D-IV) atau sarjana (S-1) Akuntansi dan Non Akuntansi yang diselenggarakan oleh Perguruan Tinggi Indonesia atau luar negeri yang telah disetarakan oleh instansi yang berwenang sesuai dengan ketentuan peraturan perundang-undangan di bidang pendidikan. Calon peserta yang berasal dari D-IV atau S-1 Non Akuntansi harus mengikuti matrikulasi yang diselenggarakan oleh penyelenggara PPAk yang mencakup common body of knowledge dalam bidang akuntansi,meliputi antara lain: akuntansi keuangan, akuntansi manajemen dan biaya, auditing, sistem informasi, perpajakan, hukum bisnis, manajemen keuangan, dan ekonomi.

Pernyataan ini dipertegas oleh Peraturan Menteri Pendidikan dan Kebudayaan Republik Indonesia Nomor 153 Tahun 2014 (Indonesia, 2014) tentang penyelenggaraan pendidikan profesi akuntan pasal 1 menyatakan bahwa pendidikan profesi akuntan merupakan jenis pendidikan tinggi setelah program sarjana atau setara yang menyiapkan mahasiswa dalam pekerjaan yang memerlukan persyaratan keahlian khusus di bidang akuntansi. Penelitian ini dilakukan pada mahasiswa non akuntansi dikarenakan adanya peraturan baru yakni peraturan Menteri pendidikan dan kebudayaan Republik Indonesia Nomor 153 Tahun 2014 tentang penyelenggaraan pendidikan profesi akuntan pasal 4 ayat 2 menyatakan bahwa mahasiswa pendidikan profesi akuntansi yang berasal dari jurusan non akuntansi wajib memiliki pengetahuan dan kompetensi dasar dibidang akuntansi yang relevan sesuai standar nasional pendidikan profesi akuntansi.

Hal ini berarti, tidak hanya mahasiswa jurusan akuntansi saja yang dapat mengikuti Pendidikan Profesi Akuntansi (PPAk), tetapi mahasiswa non akuntasi seperti mahasiswa manajemen, mahasiswa ekonomi pembangunan, mahasiswa matematika dan sebagainya juga dapat mengikuti Pendidikan Profesi Akuntansi (PPAk), akan tetapi mahasiswa non akuntansi ini wajib memiliki pengetahuan dan kompetensi dasar di bidang akuntansi

Manusia mempunyai aspek psikis yang mendorongnya untuk memperolehtujuannya yang disebut minat.Orang yang mempunyai minat pada objek tertentu, memiliki kecenderungan untuk menaruh perhatian ataupun merasakan kesenangan yang lebih tinggi untuk objek tersebut. Tetapi, jika objek tersebut tidak memberikan kesenangan, menyebabkan objek tersebut tidak akan diminati oleh orang tersebut. Minat mempunyai dampak yang tinggi untuk 
memperoleh prestasi ketika bekerja, karir ataupun jabatan. Orang yang tidak mempunyai minat yang baik dalam pekerjaan yang dilaksanakannya tidak akan mungkin dapat melaksanakan pekerjaannya dengan baik.

Motivasi yang ada pada seseorang akan mewujudkan suatu prilaku yang diarahkan pada tujuan mencapai sasaran kepuasan. Jadi, motivasi bukanlah yang dapat diamati tetapi adalah hal yang dapat disimpulkan adanya karena sesuatu prilaku yang tampak.

Membangun produktivitas dan motivasi pekerja ada dua hal yang harus dilakukan, yaitu carilah pembayaran pekerjaan individual seseorang dan bantu mereka mencapai pembayaran untuk setiap tugas tambahan yang diberikan sehingga baik kebutuhan instansi maupun individu tercapai. Motivasi sosial ialah dorongan individu untuk melaksanakan kegiatan bertujuan memperoleh nilai sosial, mendapatkan penghargaan atau pengakuan dari lingkungannya tempat individu tersebut berada. Motivasi sosial memiliki keterkaitan dengan seseorang yang ingin eksistensi dan prestasi yang didapatkannya dapat diakui oleh lingkungannya. Seseorang yang memperoleh gelar akuntan, akan muncul rasa puas secara batin karena eksistensinya diakui oleh lingkungannya. Penelitian McClintock 1972), Indrawati (2009),(Chevallier, Grèzes, Molesworth, Berthoz, \& Happé, 2012), (Nurhayani, 2012) menyatakan bahwa variabel motivasi sosial berpengaruh positif terhadap minat mahasiswa akuntansi untuk mengikuti Pendidikan Profesi Akuntansi (PPAk).

Penelitian yang dilakukan Yusuf, 2000 dalam (Widyastuti, 2004) untuk mengetahui kualitas lulusan jurusan akuntansi, menyatakan bahwa mutu lulusan dari penerapan kurikulum program S-1 jurusan akuntansi yang berlaku selama ini sering dipertanyakan, lebih-lebih jika bekerja atau membuka kantor akuntan publik kemampuan lulusan pada umumnya dipandang kurang memadai. Elemen kualitas atau kompetensi merupakan hal yang sangat diperhatikan dalam profesi akuntansi, khususnya profesi akuntan publik.

Munawir, 1999 dalam (Widyastuti, 2004) menyatakan bahwa kompetensi auditor ditentukan oleh tiga faktor: Pendidikan formal tingkat universitas, yaitu dengan menjadi Sarjana Ekonomi jurusan Akuntansi.Namun pada saat ini diharuskan bagi lulusan Sarjana Ekonomi jurusan Akuntansi baik itu dari Perguruan Tinggi Negeri maupun Swasta untuk mengikuti Pendidikan Profesi Akuntansi (PPAk) sebab PPAk dapat memberikan kontribusi untuk menjadi seorang akuntan yang professional. Pelatihan teknis dan pengalaman dalam bidang auditing antara lain memiliki pengalaman kerja di Kantor Akuntan Publik minimal 3 tahun. Pendidikan professional yang berkelanjutan selama menjalani karir sebagai auditor dengan mengikuti seminar, lokakarya dan Simposium Nasional Akuntansi (SNA).

Motivasi Karir merupakan suatu keahlian seseorang di bidang ilmunya yang dinilai berdasarkan pengalaman kerja yang akan memberikan kontribusi kepada organisasi. Motivasi karir adalah dorongan yang timbul dalam diri seseorang untuk meningkatkan kemampuan pribadinya dalam rangka mencapai kedudukan, jabatan dan karir yang lebih baik dari sebelumnya. Pernyataan ini didukung oleh teori hierarki kebutuh Maslow yakni kebutuhan akan penghargaan, yang merupakan kebutuhan yang meliputi faktor-faktor internal seperti harga diri, otonomi, dan prestasi, serta faktor-faktor eksternal seperti 
status, pengkuan dan perhatian. Institusi pendidikan mempunyai pengaruh besar terhadap perkembangan karir seorang akuntan.

Auditor yang mempunyai latar belakang pendidikan(London, 1983) menyatakan bahwa motivasi karir dipandang sebagai konstruk multidimensi. (McCormick, 1985) mengemukakan bahwa motivasi kerja ialah keadaan yang berimplikasi mengarahkan, membangkitkan serta memelihara perbuatan yang memiliki keterkaitan dengan lingkungan kerjanya.

(Farmer, 1976) menyatakan bahwa motivasi karir yang diwakili oleh pekerjaan terutama oleh kaum perempuan sangat dipengaruhi oleh faktor lingkungan, latar belakang dan variabel psikologisnya. (Noe, R. A., Noe, A. W., \& Bachhuber, 1980) menyatakan bahwa motivasi karir terdiri dari tiga karakteristik tujuan dari penelitian tersebut untuk menyelidiki korelasi potensi motivasi karir.

Karir juga dianggap sebagai bentuk promosi dalam mendapatkan pekerjaan yang memiliki beban tanggung jawab lebih besar ataupun kenaikan posisi kerja yang lebih tinggi yang bertujuan supaya mereka mempunyai karir yang cemerlang (Kermis, 2011). Penelitian yang dilakukan oleh(Farmer, 1976), (Nisa, 2012), (Kusumastuti \& Waluyo, 2013), dan Yudhistira (2014) menunjukkan bahwa motivasi karir berpengaruh positif terhadap minat mahasiswa akuntansi untuk mengikuti PPAk.

Motivasi ekonomi ialah dorongan dari diri individu agar mendapatkan keinginannya yakni penghargaan keuangan atau finansial, karena pada dasarnya keuangan atau financial ialah kebutuhan manusia.Penghargaan finansial ialah bentuk dari sistem pengendalian manajemen.Umumnya penghargaan finansial terdiri dari penghargaan langsung serta tidak langsung (Tracey Mc, 2010).

Penghargaan langsung dapat berupa dibayarnya gaji lembur, upah dasar atau pokok, laba yang dibagikan, opsi saham dan lain sebagainya, sedangkan penghargaan tidak langsung ialah tunjangan biaya sakit, asuransi, program pensiun dan lain sebagainya. (Joseph Sirgy et al., 2013) menyatakan bahwa orangorang yang termotivasi secara ekonomis akan mampu mengevaluasi standar hidup mereka dengan menggunakan kemampuan sesuai dengan konteks cita-cita yang sudah mereka tetapkan berdasarkan standar hidup mereka.

Penelitian yang dilakukan oleh (Benny, 2006), menunjukkan bahwa motivasi ekonomi berpengaruh terhadap minat mahasiswa akuntansi untuk mengikuti PPAk. Hasil penelitian tersebut juga didukung oleh hasil penelitian dari (Dewi \& Setiawanta, 2008), (Kusumastuti \& Waluyo, 2013), Yudhistira (2014) yang menyatakan bahwa motivasi ekonomi berpengaruh positif signifikan terhadap minat mahasiswa mengikuti PPAk. Berdasarkan uraian di atas mengenai penghargaan finansial dari pekerjaan.

Gelar ialah identitas seseorang atas keahliannya dalam ilmu tertentu.Sebelum adanya PPAk, hanya universitas negeri yang sudah ditugaskan.Negara yang bisa mendapatkan gelar akuntan tanpa melaksanakan ujian Negara.Tetapi saat ini, diadakannya PPAk, seluruh mahasiswa yang berasal dari Universitas Swasta maupun Negeri harus mengikuti ujian supaya mendapatkan gelar S.Ak. Yang membedakan gelar S.E dengan gelar S.Ak ialah gelar S.Ak lebih menunjukkan kualifikasiserta spesifikasi seseorang yang memiliki profesi di bidang akuntansi dibandingkan seseorang lulusan S1 akuntansi yang bergelar S.E. Penelitian yang dilakukan oleh (Ayuningtyas, 2012) 
menunjukkan bahwa ada pengaruh positif antara motivasi gelar dan minat untuk mengikuti program PPAk.

Teori hierarki ini dikemukakan oleh seorang psikolog yang bernama Abraham Maslow pada tahun 1943.Teori ini mengemukakan 5 kebutuhan hidup manusia berdasarkan Hirarkinya yaitu mulai dari kebutuhan yang mendasar hingga kebutuhan yang lebih tinggi.Teori ini kemudian dikenal dengan Teori Maslow atau Teori Hirarki Kebutuhan.Hirarki kelima kebutuhan. Hirarki kelima kebutuhan tersebut diantaranya adalah: Kebutuhan fisiologis (physiological needs) Kebutuhan keamanan (safety needs), Kebutuhan sosial (social needs), Kebutuhan penghargaan (Esteem needs), Kebutuhan aktualisasi diri (Self Actulization),

Pada tahun 1969, Clayton Alderfer mempublikasikan artikel tentang kebutuhan manusia yang berjudul "An Emperical Test of a New Theory of Human Need".Teori tersebut merupakan teori alternatif terhadap teori Hirarki Maslow. Teori ini mengemukakan tiga kebutuhan manusia yaitu: Kebutuhan eksistensi (Exsistence needs) yaitu kebutuhan akan pemenuhan faktor fisiologis dan materialistis termasuk kebutuhan akan rasa aman. Kebutuhan hubungan (Releated needs) yaitu kebutuhan untuk memiliki hubungan dengan orang lain. Kebutuhan Pertumbuhan (Growth needs) yaitu kebutuhan atau keinginan untuk bertumbuh dan mencapai potensi diri secara maksimal.

Seorang psikolog Amerika serikat yang bernama David McCelland mengemukakan hubungan antara kebutuhan pencapaian, afiliasi dan kekuasaan pada akhir 1940-an. Teori kebutuhan (McClelland., 1987) diantaranya adalah: need for achievement merupakan kebutuhan untuk mencapai sukses yang diukur berdasarkan standar kesempurnaan dalam diri seseorang. need for affiliation merupakan kebutuhan akan kehangatan dan dukungan dalam hubungan dengan orang lain. Need for power merupakan kebutuhan untuk menguasai dan mempengaruhi orang lain.

Frederick Herzberg adalah seseorang psikolog Amerika Serikat yang mengemukakan Teori Motivator-Hygiene Hezberg.Teori tersebut didapat dari penelitian terhadap 203 akuntan dan teknisi di area Pittsburgh, Amerika Serikat.Dari hasil penelitian tersebut ditemukan dua faktor yang berbeda yaitu kepuasan dan tidak kepuasan dalam bekerja. Teori Motivator-Hygiene Herzberg juga dikenal dengan Teori dua faktor, yaitu: Kepuasan bekerja, yaitu faktor yang berkaitan dengan pengakuan, prestasi, tanggung jawab yang memberikan kepuasaan positif. Faktor ini sering disebut juga dengan faktor motivator. Ketidakpuasan bekerja, yaitu faktor yang berkaitan dengan gaji, keamanan bekerja dan lingkungan kerja yang seringkali memberikan ketidakpuasan. Faktor ini sering disebut dengan Faktor Hygiene.

Istilah profesi berasal dari bahasa Yunani, proffesues berarti suatu kegiatan atau suatu pekerjaan yang dihubungkan dengan sumpah atau janji yang bersifat religius, sehingga ada ikatan batin bagi seseorang yang memiliki profesi tersebut untuk tidak melanggar dan memelihara kesucian profesinya. Pandangan yang dikemukakan oleh (Paisey, 2005) menunjukkan bahwa asal mula istilah profesional yaitu apa yang profesional miliki (profess), mereka memiliki (profess) pengetahuan yang lebih baik dibandingkan yang orang lain pada hal tertentu. Profesi memiliki arti sebuah pekerjaan yang membutuhkan pelatihan dan penguasaan terhadap suatu pengetahuan dan keahlian khusus. 
Weygant et al. (1966) menyatakan bahwa pada umumnya profesi akuntan diperlukan pada empat bidang, yaitu public accounting, private accounting, non-forprofit acounting, dan pendidik.Profesi akuntan merupakan pihak yang menjembantani hubungan antara pihak manajemen dan pemilik atau pihak manajemen yang mengelola suatu unit usaha (Jensen \& Meckling, 1976). Ciri-ciri suatu profesi sebagaimana disebut oleh (Benny, 2006) antara lain, adalah keahlian yang dimiliki seseorang yang diperoleh melalui proses pendidikan yang teratur dan dibuktikan dengan sertifikat yang diperoleh dari lembaga yang diakui dan memberikan kewenangan untuk melayani masyarakat dalam bidang keahlian tersebut.

Peraturan Menteri Pendidikan dan kebudayaan Republik Indonesia Nomor 153 tahun 2014 tentang penyelenggaraan pendidikan program profesi akuntansi pasal 1 menyatakan bahwa pendidikan program profesi akuntansi merupakan jenis pendidikan tinggi setelahprogram sarjana atau setara yang menyiapkan mahasiswa dalam pekerjaan yang memerlukan persyaratan keahlian khusus dibidang akuntansi.

PPAk adalah suatu usaha yang bertujuan untuk menghasilkan akuntan professional dengan standarisasi kualitas akuntan di Indonesia.Mahasiswa non akuntansi selayaknya diarahkan untuk memberi pemahaman konseptual yang didasarkan pada penalaran sehingga ketika akhirnya masuk ke dalam dunia praktik dapat beradaptasi dengan keadaan sebenarnya dan memiliki resistance to changeyang rendah terhadap gagasan perubahan atau pembaruan yang menyangkut profesinya tersebut (Suwardjono, 2012).

Peraturan Ikatan Akuntansi Indonesia Nomor 2 tahun 2015 tentang mekanisme pelaksanaan ujian Chartered accountant Indonesia bagi mahasiswa pendidikan program profesi akuntan menyatakan bahwa Chartered accountant Indonesia adalah kualifikasi akuntan profesional yang dittetapkan oleh IAI yang pemegang sertifikatnya akan mendapatkan sebutan (designation) profesi sebagai Chartered acountant Indonesia disingkat "CA". Ujian Chartered Accountant Indonesia (CA) adalah ujian sertifikasi akuntan profesional yang diselenggarakan oleh IAI, peserta ujian CA merupakan mahasiswa aktif PPAk. Ujian CA diselenggarakan atas prinsip dasar, yaitu: kompetansi, objektivitas, independen, integritas, transparan, fairness, adil, dan bertanggung jawab.

Teori dari Vroom (1964) dalam Lunenberg (2011) tentang cognitive Theory of Motivation menjelaskan bahwa masyarakat percaya ada hubungan antara usaha yang mereka tunjukan dalam perusahaan, kinerja dari usaha tersebut dan penghargaan yang mereka terima dari usaha dan kinerja mereka. Dalam teori ini dijelaskan tinggi rendahnya motivasi seseorang ditentukan oleh tiga komponen yaitu ekspetasi (harapan) keberhasilan pada suatu tugas. dan instrumentalis, yaitu penilaian tentang apa yang akan terjadi jika berhasil dalam melakukan suatu tugas

Penelitian ini mengenai pengaruh motivasi sosial pada minat mahasiswa non akuntansi untuk mengikuti Pendidikan Profesi Akuntansi (PPAk) sejauh ini masih cukup sedikit. (Chevallier et al., 2012) dalam penelitiannya mengungkapkan bahwa motivasi sosial dapat meningkatkan minat pada Austism Spektrum Disorders (ASD), hal ini menunjukkan bahwa motivasi sosial dapat mengkapitalisasi pada temuan terbaru dan memberikan gambaran terbaru terkait motivasi sosial pada perilaku, biologis, dan evolusi. 
Penelitian yang dilakukan (McClintock, 1972), (Nisa, 2012), (Nurhayani, 2012), menunjukkan bahwa motivasi sosial berpengaruh positif terhadap minat mahasiswa akuntansi untuk mengikuti Pendidikan Profesi Akuntansi. Penelitian tersebut bertentangan dengan penelitian yang dilakukan oleh (Ayuningtyas, 2012) menunjukkan bahwa motivasi sosial tidak berpengaruh signifikan terhadap mahasiswa akuntansi untuk mengikuti PPAk. Berdasarkan uraian di atas mengenai motivasi sosial maka dapat diajukan hipotesis sebagai berikut:

$\mathrm{H}_{1}$ : Motivasi sosial berpengaruh pada minat mahasiswa non akuntansi untuk mengikuti Pendidikan Profesi Akuntansi (PPAk).

Penelitian yang dilakukan oleh (Vesparalis, 2017) menunjukan bahwa motivasi kualitas memiliki pengaruh positif terhadap minat mahasiswa akuntansi dalam internal auditor. Hal ini berarti jika mahasiswa akuntansi, maka akan meningkatkan minat mahasiswa akuntansi menjadi auditor internal. Penelitian yang dilakukan oleh (Benny, 2006),(Dewi \& Setiawanta, 2008), (Nisa, 2012), (Kusumastuti \& Waluyo, 2013), (Purnamasari, 2014) menunjukkan bahwa motivasi kualitas berpengaruh positif terhadap minat mahasiswa akuntansi untuk mengikuti PPAk.

Penelitian tersebut bertentangan dengan penelitian yang dilakukan (Widyastuti, 2004) menunjukkan bahwa motivasi kualitas tidak berpengaruh signifikan terhadap minat mahasiswa akuntansi untuk mengikuti PPAk. Berdasarkan uraian di atas mengenai motivasi kualitas maka dapat diajukan hipotesis sebagai berikut:

$\mathrm{H}_{2}$ : Motivasi kualitas berpengaruh pada minat mahasiswa non Akuntansi untuk mengikuti Pendidikan Profesi Akuntansi (PPAk).

(Noe, R. A., Noe, A. W., \& Bachhuber, 1980) menyatakan bahwa motivasi karir terdiri dari tiga karateristik individu yaitu identitas karir, wawasan karir, dan ketahuan karir, tujuan dari penelitian ini adalah untuk menyelidiki korelasi potensi motivasi karir. (Farmer, 1976) menyatakan bahwa motivasi karir yang diwakili oleh pekerjaan terutama oleh kaum perempuan sangat dipengaruhi oleh faktor lingkungan, latar belakang, dan variabel psikologi mereka.Penelitian ini dilakukan oleh (Vesparalis, 2017) menunjukkan bahwa motivasi karir memiliki pengaruh positif terhadap minat mahasiswa akuntansi dalam internal auditor.Hal ini berarti semakin tinggi motivasi karir yang dimiliki mahasiswa maka semakin tinggi juga minatnya.

Motivasi karir ini meliputi bekerja keras untuk mendapatkan kedudukan sesuai keahlian dan mengenai semua rintangan dalam mencapai kesuksesan mengejar karir. Penelitian yang dilakukan oleh (Farmer, 1976), (Widyastuti, 2004), (Benny, 2006), (Lisnasari, 2008), (Nisa, 2012), (Nurhayani, 2012), (Kusumastuti \& Waluyo, 2013) menujukkan bahwa motivasi karir berpengaruh positif terhadap minat mahasiswa akuntansi untuk mengikuti PPAk. Penelitian tersebut bertentangan dengan penelitian yang dilakukan (Dewi \& Setiawanta, 2008), (Purnamasari, 2014) menunjukkan bahwa motivasi karir tidak berpengaruh signifikan terhadap minat mahasiswa akuntansi untuk mengikuti PPAk. Berdasarkan uraian diatas mengenai motivasi karir maka dapat diajukan hipotesis sebagai berikut:

$\mathrm{H}_{3}$ : Motivasi karir berpengaruh pada minat mahasiswa non akuntansi untuk mengikuti Pendidikan Profesi Akuntansi (PPAk). 
Motivasi ekonomi meliputi pemikiran tentang gaji awal yang besar, bonus, dan memiliki kesempatan kenaikan gaji yang cepat. Penelitian yang dilakukan oleh (Frank, 1940), (Nurhayani, 2012), (Kusumastuti \& Waluyo, 2013), menunjukkan bahwa motivasi ekonomi bepengaruh positif terhadap minat mahasiswa akuntansi untuk mengikuti PPAk.

Penelitian tersebut bertentangan dengan penelitian yang dilakukan oleh (Widyastuti, 2004), (Benny, 2006), (Lisnasari, 2008), (Dewi \& Setiawanta, 2008), (Purnamasari, 2014) menunjukkan bahwa motivasi ekonomi tidak berpengaruh terhadap minat mahasiswa akuntansi untuk mengikuti PPAk. Berdasarkan uraian di atas mengenai motivasi ekonomi maka dapat diajukan hipotesis sebagai berikut:

$\mathrm{H}_{4}$ : Motivasi ekonomi berpengaruh pada minat mahasiswa non akuntansi untuk mengikuti Pendidikan Profesi Akuntansi (PPAk).

Pengaruh motivasi gelar terhadap minat mahasiswa mengikuti PPAk. Sebelum ada PPAk, mahasiswa S1 akuntansi universitas negeri yang telah lulus dapat memperoleh gelar akuntan tanpa mengikuti ujian Negara. Namun, setelah adanya PPAk, mahasiswa S1 akuntansi tidak langsung mendapat gelar sarjana akuntansi, harus mengikuti PPAk untuk memperoleh gelar akuntan.

Menurut hasil penelitian (Ayuningtyas, 2012) dan (Lisnasari, 2008) menyatakan bahwa motivasi gelar berpengaruh terhadap minat mahasiswa mengikuti PPAk. Berdasarkan uraian diatas maka dapat diajukan hipotesis sebagai berikut:

$\mathrm{H}_{5}$ : Motivasi gelar berpengaruh pada minat mahasiswa untuk mengikuti PPAk.

\section{METODE PENELITIAN}

Penelitian ini merupakan penelitian kuantitatif yang berbentuk asosiatif. Penelitian ini dilakukan untuk mengetahui pengaruh motivasi kualitas, motivasi karir, motivasi ekonomi, motivasi gelar motivasi sosial terhadap minat mahasiswa non akuntansi untuk mengikuti pendidikan profesi akuntansi dengan minat mengikuti PPAk sebagai variabel terikat.

Lokasi dari penelitian ini bertempat di Fakultas Ekonomi dan Bisnis Universitas Udayana yakni pada mahasiswa non akuntansi program S1 reguler angkatan 2016. Lokasi tersebut dipilih karena sebagian besar mahasiswa yang mengikuti PPAk berasal dari Fakultas Ekonomi dan Bisnis Universitas Udayana. Adapun objek dalam penelitian ini adalah motivasi sosial, motivasi kualitas, motivasi karir, motivasi ekonomi, motivasi gelar, dan minat mengikuti Pendidikan Profesi Akuntansi (PPAk).

Data kualitatif dalam penelitian ini adalah nama-namaMahasiswa Non akuntansi di Fakultas Ekonomi dan Bisnis Univeristas Udayana angkatan 2016 program reguler. Data kuantitatif dalam penelitian ini berupa hasil kuesioner.

Dalam penelitian ini data primer diperoleh melalui kuesioner yang telah disebar kepada semua Mahasiswa non Akuntansi program S1 reguler angkatan 2016 di Fakultas Ekonomi dan Bisnis Unversitas Udayana. Populasi dalam penelitian adalah semua mahasiwa non akuntansi program S1 reguler angkatan $2016 \mathrm{di}$ Fakultas Ekonomi Dan Bisnis Universitas Udayana.Berikut populasi pada Tabel 
3.7 jumlah mahasiswa non akuntansi program S1 reguler angkatan 2016 di Fakultas Ekonomi Dan Bisnis Universitas Udayana.

Tabel 1. Klasifikasi Jumlah Sampel Berdasarkan Jumlah Mahasiswa Non Akuntansi Program S1 Reguler Angkatan 2016 di Fakultas Ekonomi Dan Bisnis Universitas Udayana

\begin{tabular}{cc}
\hline Jurusan & Angkatan 2016 \\
\hline Manajemen & 153 \\
Ekonomi pembangunan & 136 \\
Total & 289 \\
\hline
\end{tabular}

Sumber: Data Penelitian, 2019

Sampel dalam penelitian ini adalah keseluruhan jumlah populasi.Metode penelitian sampel yang dipilih adalah non probability sampling dengan teknik sampling jenuh. Metode pengumpulan data dalam penelitian ini dilakukan dengan menggunakan metode survei yaitu menyebarkan kuesioner.

Perhitungan analisa yang digunakan pada penelitian ini yaitu regresi linear berganda dengan bantuan computer program Stastical Produst and Service Solution (SPSS). Analisis regresi linear berganda adalah pengujian yang dilakukan untuk mengetahui ketergantungan satu variabel terkait pada satu variabel terikat pada satu variabel bebas dengan atau tanpa variabel moderasi. Analisis regresi linear berganda dilakukan untuk mengetahui pengaruh motivasi pada minat mahasiswa non akuntansi untuk mengikuti Pendidikan Profesi Akuntansi (PPAk) yang akan diuji dengan tingkat signifikansi $\alpha=5 \%$. Rumus dari model regresi linier berganda adalah:

$Y=\alpha+\beta 1 X 1+\beta 2 X 2+\beta 3 X 3+\beta 4 X 4+\beta 5 X 5+\beta 6 X 6+e$

Keterangan:

$\mathrm{Y}=$ Minat mengikuti PPAk

$\alpha=$ Nilai konstanta

$\mathrm{X}_{1}=$ Motivasi sosial

$X_{2}=$ Motivasi kualitas

$\mathrm{X}_{3}=$ Motivasi Karir

$\mathrm{X}_{4}=$ Motivasi ekonomi

$\mathrm{X}_{5}=$ Motivasi gelar

$\beta_{1}=$ Koefisien regresi dari Motivasi sosial (X1)

$\beta_{2}=$ Koefisien regresi dari Motivasi kualitas (X2)

$\beta_{3}=$ Koefisien regresi dari Motivasi karir (X3)

$\beta_{4}=$ Koefisien regresi dari Motivasi ekonomi (X4)

$\beta_{5}=$ Koefisien regresi dari Motivasi gelar (X5)

$\mathrm{e}=$ eror (tingkat kesalahan penggangu)

\section{HASIL DAN PEMBAHASAN}

Jumlah sampel yang digunakan dalam penelitian ini sebanyak 169 responden. Gambaran responden ini terdiri dari penyebaran dan pengembalian responden serta profil responden secara individual. Penyebaran kuesioner diantar langsung kepada responden dan penyebaran kuesioner dilakukan pada bulan November 2018. Ringkasan penyebaran dan pengembalian kuesioner penelitian ditunjukkan dalam tabel 2. 
Tabel 2. Penyebaran dan Pengembalian Kuesioner

\begin{tabular}{ll}
\hline \multicolumn{1}{c}{ Keterangan } & \multicolumn{1}{c}{ Jumlah } \\
\hline Kuesioner yang disebar & 289 eksemplar \\
Kuesioner yang kembali & 169 eksemplar \\
Kuesioner yang tidak kembali & 120 eksemplar \\
Response rate & $58,4 \%$ \\
Kuesioner yang pengisiannya tidak lengkap & 0 eksemplar \\
Kuesioner yang dapat diolah & 169 eksemplar \\
Persentase kuesioner yang dapat diolah & $58,4 \%$
\end{tabular}

Sumber:Data Penelitian, 2019

Pada Tabel 2. terlihat bahwa kuesioner yang dibagikan kepada responden dalam penelitian ini berjumlah 289 kuesioner. Kuesioner yang terkumpul sebanyak 169 eksemplar. Jadi response rate dalam penelitian ini sebesar 58,4\%. Ini diakibatkan karena ketidakmampuan peneliti dalam menyebarkan seluruh kuesioner, karena keterbatasan waktu dan beberapa responden sedang cuti.

Tabel 3. Hasil Uji Reliabilitas

\begin{tabular}{lcc}
\hline \multicolumn{1}{c}{ Variabel } & Nilai Cronbach alpha & Keterangan \\
\hline Motivasi sosial & 0,986 & Reliabel \\
Motivasi kualitas & 0,934 & Reliabel \\
Motivasi karir & 0,957 & Reliabel \\
Motivasi ekonomi & 0,945 & Reliabel \\
Motivasi gelar & 0,939 & Reliabel \\
Minat mengikuti PPAK & 0,962 & Reliabel \\
\hline
\end{tabular}

Sumber: Data Penelitian,2019

Tabel 3. Pengujian cronbach's alpha menunjukan bahwa semua instrumen variabel lebih besar dari 0,60. Hal ini menunjukkan bahwa semua variabel telah memenuhi syarat reliabilitas atau dapat dikatakan reliabel sehingga dapat digunakan dalam penelitian ini.

Berdasarkan Tabel 4. dapat diketahui bahwa nilai koefisien korelasi untuk hasil uji validitas seluruh variabel besarnya $>0,3$ dengan signifikansi lebih kecil dari 0,05. Dengan demikian dapat diinterpretasikan bahwa setiap item indikator instrumen dalam penelitian ini adalah valid.

Tabel 4. Hasil Uji Validitas

\begin{tabular}{lcccc}
\hline Variabel & $\begin{array}{c}\text { Item } \\
\text { pernyataan }\end{array}$ & $\begin{array}{c}\mathrm{r} \\
\text { hitung }\end{array}$ & $\begin{array}{c}\mathrm{r} \\
\text { tabel }\end{array}$ & Keterangan \\
\hline Motivasi sosial & X1.1 & 0,981 & 0,3 & Valid \\
& X1.2 & 0,980 & 0,3 & Valid \\
X1.3 & 0,964 & 0,3 & Valid \\
& X1.4 & 0,980 & 0,3 & Valid \\
Motivasi Kualitas & X1.5 & 0,964 & 0,3 & Valid \\
& X2.1 & 0,777 & 0,3 & Valid \\
& X2.2 & 0,910 & 0,3 & Valid \\
& X2.3 & 0,865 & 0,3 & Valid \\
& X2.4 & 0,892 & 0,3 & Valid \\
\hline
\end{tabular}

Bersambung ... 
Lanjutan Tabel 4.

\begin{tabular}{lllll}
\hline & X2.5 & 0,868 & 0,3 & Valid \\
Motivasi karir & X3.6 & 0,910 & 0,3 & Valid \\
& X3.2 & 0,852 & 0,3 & Valid \\
X3.3 & 0,894 & 0,3 & Valid \\
X3.4 & 0,876 & 0,3 & Valid \\
X3.5 & 0,946 & 0,3 & Valid \\
X3.6 & 0,946 & 0,3 & Valid \\
& & & & Valid \\
\hline
\end{tabular}

Sumber: Data Penelitian, 2019

Analisis regresi linear berganda digunakan untuk mengetahui pengaruh antara variabel bebas terhadap variabel terikat. Dalam penelitian ini analisis regresi linear berganda digunakan untuk mengetahui besarnya pengaruh motivasi pada minat mahasiswa non akuntansi untuk mengikuti pendidikan profesi akuntansi.

Tabel 5. Hasil Analisis Regresi Berganda

\begin{tabular}{|c|c|c|c|c|c|}
\hline \multirow[t]{2}{*}{ Model } & \multicolumn{2}{|c|}{ Unstandardized Coefficients } & \multirow{2}{*}{$\begin{array}{c}\begin{array}{c}\text { Standardized } \\
\text { Coefficients }\end{array} \\
\text { Beta }\end{array}$} & \multirow[t]{2}{*}{$\mathrm{t}$} & \multirow[t]{2}{*}{ Sig. } \\
\hline & $\mathrm{B}$ & Std. Error & & & \\
\hline $\begin{array}{l}1 \\
\text { (Constanst) }\end{array}$ & $-1,919$ & 0,441 & & $-4,352$ & 0,000 \\
\hline $\mathrm{X} 1$ & 0,322 & 0,011 & 0,556 & 28,565 & 0,000 \\
\hline $\mathrm{X} 2$ & 0,147 & 0,010 & 0,264 & 15,125 & 0,000 \\
\hline X3 & 0,269 & 0,010 & 0,467 & 25,991 & 0,000 \\
\hline $\mathrm{X} 4$ & 0,193 & 0,012 & 0,293 & 15,462 & 0,000 \\
\hline X5 & 0,207 & 0.010 & 0,353 & 20,114 & 0,000 \\
\hline
\end{tabular}

Sumber: Data Penelitian,2019

Persamaan regresi yang terbentuk dari pengolahan data ditunjukkan sebagai berikut.

$$
Y=-1,919+0,322 X_{1}+0,147 X_{2}+0,269 X_{3}+0,193 X_{4}+0,207 X_{5}
$$

Nilai konstanta a sebesar $-1,919$ artinya jika variabel motivasi sosial, motivasi kualitas, motivasi karir, motivasi ekonomi, motivasi gelar dianggap konstan (tetap atau tidak ada perubahan), maka minat mengikuti PPAk sebesar -1,919. Nilai koefisien $b_{1}$ sebesar 0,322 artinya jika nilai variabel motivasi sosial meningkat sebesar satu satuan maka minat mengikuti PPAk meningkat sebesar 0,322 dengan asumsi variabel motivasi kualtias, motivasi karir, motivasi ekonomi dan motivasi gelar tetap konstan. Nilai koefisien $b_{2}$ sebesar 0,147 artinya jika motivasi kualitas meningkat sebesar satu satuan maka minat mengikuti PPA meningkat sebesar 0,147 dengan asumsi variabel motivasi sosial, motivasi karir, motivasi ekonomi, motivasi gelar tetap konstan.

Nilai koefisien $b_{3}$ sebesar 0,269 artinya jika motivasi karir meningkat sebesar satu satuan maka minat mengikuti PPAk naik sebesar 0,269 dengan asumsi variabel variabel motivasi sosial, motivasi kualitas, motivasi ekonomi dan motivasi gelar tetap konstan. Nilai koefisien $b_{4}$ sebesar 0,193 artinya jika motivasi ekonomi meningkat sebesar satu satuan maka minat mengikuti PPAk naik sebesar 0,193 dengan asumsi variabel motivasi sosial, motivasi kualitas, motivasi karir dan motivasi gelar tetap konstan. 
Nilai koefisien $b_{5}$ sebesar 0,207 artinya jika motivasi gelar meningkat sebesar satu satuan maka minat mengikuti PPAk naik sebesar 0,207 dengan asumsi variabel motivasi sosial, motivasi kualitas, motivasi karir, motivasi ekonomi tetap konstan.

Tabel 6. Nilai Koefisien Determinasi (Uji R²)

\begin{tabular}{lllll}
\hline Model & $\mathrm{R}$ & R Square & $\begin{array}{l}\text { Adjusted } \\
\text { Square }\end{array}$ & $\begin{array}{l}\mathrm{R} \\
\text { Std. Error of the } \\
\text { Estimate }\end{array}$ \\
\hline 1 & $0,977^{a}$ & 0,954 & 0,953 & 0,39676
\end{tabular}

Sumber: Data Penelitian,2019

Berdasarkan Tabel 6. nilai adjusted $\mathrm{R}^{2}$ sebesar 0,953, ini berarti sebesar 95,3 persen variabel motivasi sosial, motivasi kualitas, motivasi karir, motivasi ekonomi, dan motivasi gelar mempengaruhi minat mengikuti PPAK sedangkan sisanya sebesar 4,7 persen dipengaruhi oleh variabel lain yang tidak dimasukan dalam penelitian.

Tabel 7. Uji Kelayakan Model (Uji F)

\begin{tabular}{cccccc}
\hline Model & $\begin{array}{c}\text { Sum of } \\
\text { Squares }\end{array}$ & $d f$ & Mean Square & F & Sig. \\
\hline 1 & 532,341 & 5 & 106,468 & 676,331 & $0,000^{\mathrm{a}}$ \\
$\begin{array}{c}\text { Regression } \\
\text { Residual }\end{array}$ & 25,659 & 163 & 0,157 & & \\
Total & 558,000 & 168 & & & \\
\hline
\end{tabular}

Sumber: Data Penelitian,2019

Berdasarkan Tabel 7. diperoleh nilai dari signifikansi 0,000 yang lebih kecil dari 0,05. Ini berarti bahwa ada pengaruh antara variabel motivasi sosial, motivasi kualitas, motivasi karir, motivasi ekonomi, motivasi gelar secara simultan terhadap variabel minat mengikuti PPAk.

Berdasarkan hasil pengujian secara empiris terbukti bahwa motivasi sosial berpengaruh pada minat mahasiswa non akuntansi mengikuti pendidikan profesi akuntansi. Hal ini ditunjukkan oleh nilai sig kurang dari 0,05..Hasil penelitian memberikan makna bahwa semakin tinggi motivasi sosial mahasiswa non akuntansi maka semakin tinggi minat mengikuti PPAk.

Menurut (Buss \& Inquiry, 1997) menyatakan bahwa pentingnya status sebagai motivasi sosial akan sangat berpengaruh terhadap tingkat kecemasan yang dialami seseorang, disamping itu motivasi sosial secara psikologis mampu mengabaikan peran dari jenis kelamin seseorang. (Akerlof, 2006) menyatakan bahwa motivasi sosial dapat menyebabkan individu untuk berperilaku berbeda karena terkait dengan adanya motivasi ekonomi melatarbelakanginya. Coralie et al. (2012) mengungkapkan apabila motivasi sosial langsung diungkapkan sendiri serta tercermin dalam situasi sosial dan non sosial maka dikatakan motivasi sosial itu bersifat sederhana.

Motivasi sosial dapat diartikan sebagai suatu dorongan seseorang untuk melakukan perbuatan dengan tujuan atau bernilai sosial, memperoleh pengakuan maupun penghargaan.Dari lingkungan dimana seseorang berada.Pekerja akuntan lebih dihargai dan mendapat distrata sosial masyarakat.Kepedulian dan perhatian pada sekitar oleh seseorang akuntan.Akan meningkatkan nilai instrinsik dan nilai jual akuntan. Menurut (Widyasari, 2010) nilai-nilai sosial ditunjukan sebagai 
faktor yang mencerminkan kemampuan seseorang pada masyarakatnya, dengan kata lain nilai-nilai sosial adalah nilai seseorang dari sudut pandang orang lain di lingkungannya.

Hasil penelitian ini bersesuaian dengan yang dilakukan (McClintock, 1972), Nisa (2012), (Nurhayani, 2012), Yudhistira (2014) menunjukkan bahwa motivasi sosial berpengaruh positif terhadap minat mahasiswa akuntansi untuk mengikuti Pendidikan Profesi Akuntansi.

Berdasarkan hasil pengujian secara empiris terbukti bahwa motivasi kualitas berpengaruh pada minat mahasiswa non akuntansi mengikuti pendidikan profesi akuntansi. Hal ini ditunjukkan oleh nilai sig kurang dari 0,05. Hasil penelitian memberikan makna bahwa semakin tinggi motivasi kualitas mahasiswa non akuntansi maka semakin tinggi minat mengikuti PPAK. Maarten et al.(2009) menyatakan bahwa motivasi kualitas yang baik yang dialami oleh guru-guru didukung oleh otonomi secara struktur dan memiliki keterlibatan secara emosional akan menciptakan lingkungan sekolah yang memungkinkan siswanya untuk memenuhi kebutuhan dasar mereka yakni kompentensi dan pengetahuan. Kualitas seseorang dipengaruhi baik secara langsung maupun tidak langsung oleh tingkat pendidikannya termasuk pendidikan berkelanjutan terstruktur maupun mandiri.Maka dari itu, motivasi sering kali menjadi dorongan untuk meningkatkan kualitas memicu keinginan untuk mengikuti suatu pendidikan. Selama ini, lulusan S1 akuntansi yang membuka kantor akuntan publik ataupun bekerja di bidang akuntansi sering diragukan kualitasataukemampuannya.

Penelitian yang dilakukan oleh (Vesparalis, 2017) menunjukan bahwa motivasi kualitas memiliki pengaruh positif terhadap minat mahasiswa akuntansi dalam internal auditor. Hal ini berarti jika mahasiswa akuntansi, maka akan meningkatkan minat mahasiswa akuntansi menjadi auditor internal. Penelitian yang dilakukan oleh (Benny, 2006), (Dewi \& Setiawanta, 2008), (Nisa, 2012), (Kusumastuti \& Waluyo, 2013), Yudhistira (2014) (Purnamasari, 2014) menunjukkan bahwa motivasi kualitas berpengaruh positif terhadap minat mahasiswa akuntansi untuk mengikuti PPAk.

Berdasarkan hasil pengujian secara empiris terbukti bahwa motivasi karir berpengaruh pada minat mahasiswa non akuntansi mengikuti pendidikan profesi akuntansi. Hal ini ditunjukkan oleh nilai sig kurang dari 0,05. Hasil penelitian memberikan makna bahwa semakin tinggi motivasi karir mahasiswa non akuntansi maka semakin tinggi minat mengikuti PPAk. (Noe, R. A., Noe, A. W., \& Bachhuber, 1980) menyatakan bahwa motivasi karir terdiri dari tiga karateristik individu yaitu identitas karir, wawasan karir, dan ketahuan karir, tujuan dari penelitian ini adalah untuk menyelidiki korelasi potensi motivasi karir. (Farmer, 1976) menyatakan bahwa motivasi karir yang diwakili oleh pekerjaan terutama oleh kaum perempuan sangat dipengaruhi oleh faktor lingkungan, latar belakang, dan variabel psikologi mereka.Penelitian ini dilakukan oleh (Vesparalis, 2017) menunjukkan bahwa motivasi karir memiliki pengaruh positif terhadap minat mahasiswa akuntansi dalam internal auditor.Hal ini berarti semakin tinggi motivasi karir yang dimiliki mahasiswa maka semakin tinggi juga minatnya.

Motivasi karir ini meliputi bekerja keras untuk mendapatkan kedudukan sesuai keahlian dan mengenai semua rintangan dalam mencapai kesuksesan mengejar karir. Penelitian yang dilakukan oleh (Farmer, 1976), (Widyastuti, 2004), 
(Benny, 2006), (Lisnasari, 2008), (Nisa, 2012), (Nurhayani, 2012), Nurhayani (2012),(Kusumastuti \& Waluyo, 2013), Yudhistira (2014) menujukkan bahwa motivasi karir berpengaruh positif terhadap minat mahasiswa akuntansi untuk mengikuti PPAk.

Berdasarkan hasil pengujian secara empiris terbukti bahwa motivasi ekonomi berpengaruh pada minat mahasiswa non akuntansi mengikuti pendidikan profesi akuntansi. Hal ini ditunjukkan oleh nilai sig kurang dari 0,05. Hasil penelitian memberikan makna bahwa semakin tinggi motivasi ekonomi mahasiswa non akuntansi maka semakin tinggi minat mengikuti PPAk.

Motivasi ekonomi meliputi pemikiran tentang gaji awal yang besar, bonus, dan memiliki kesempatan kenaikan gaji yang cepat. Penelitian yang dilakukan oleh (Frank, 1940), (Nurhayani, 2012), (Kusumastuti \& Waluyo, 2013), Yudhistira (2014) menunjukkan bahwa motivasi ekonomi bepengaruh positif terhadap minat mahasiswa akuntansi untuk mengikuti PPAk. Berdasarkan hasil pengujian secara empiris terbukti bahwa motivasi gelar berpengaruh pada minat mahasiswa non akuntansi mengikuti pendidikan profesi akuntansi. Hal ini ditunjukkan oleh nilai sig kurang dari 0,05. Hasil penelitian memberikan makna bahwa semakin tinggi motivasi gelar mahasiswa non akuntansi maka semakin tinggi minat mengikuti PPAk.

Pengaruh motivasi gelar terhadap minat mahasiswa mengikuti PPAk. Sebelum ada PPAk, mahasiswa S1 akuntansi universitas negeri yang telah lulus dapat memperoleh gelar akuntan tanpa mengikuti ujian Negara. Namun, setelah adanya PPAk, mahasiswa S1 akuntansi tidak langsung mendapat gelar sarjana akuntansi, harus mengikuti PPAk untuk memperoleh gelar akuntan.Dilihat dari sisi jenjang pendidikan, S.Ak tidak menunjukan jenjang pendidikan yang lebih tinggi.Gelar S.Ak lebih menunjukan kualifikasi dan spesifikasi seseorang yang berprofesi di bidang akuntansi dibandingkan seseorang lulusan S1 akuntansi yang bergelar S.E (Raminten, 2012). Menurut hasil penelitian(Ayuningtyas, 2012) dan (Lisnasari, 2008) menyatakan bahwa motivasi gelar berpengaruh terhadap minat mahasiswa mengikuti PPAk.

\section{SIMPULAN}

Berdasarkan hasil penelitian menunjukkan bahwa motivasi sosial berpengaruh positif pada minat untuk mengikuti Pendidikan Profesi Akuntansi yang artinya semakin tinggi motivasi sosial maka semakin tinggi minat mengikutii PPAk. Motivasi kualitas berpengaruh positif pada minat untuk mengikuti Pendidikan Profesi Akuntansi yang artinya semakin tinggi motivasi kualtias maka semakin tinggi minat mengikuti PPAk. Motivasi karir berpengaruh positif pada minat untuk mengikuti Pendidikan Profesi Akuntansi yang artinya semakin tinggi motivasi karir maka semakin tinggi minat mengikuti PPAk. Motivasi ekonomi berpengaruh positif pada minat untuk mengikuti Pendidikan Profesi Akuntansi yang artinya semakin tinggi motivasi ekonomi maka semakin tinggi minat mengikuti PPAk. Motivasi gelar berpengaruh positif pada minat untuk mengikuti Pendidikan Profesi Akuntansi yang artinya semakin tinggi motivasi gelar maka semakin tinggi minat mengikuti PPAk.

Saran bagi peneliti selanjutnya yaitu, tidak hanya mahasiswa non akutansi program reguler tetapi dapat menambah responden dari mahasiswa program S1 
non reguler ataupun dari universitas yang berbeda. Saran bagi program studi yaitu dapat menjadi referensi untuk program kerja ke depannya dan dapat menyaring calon-calon akuntan dari berbagai jurusan, tidak hanya akuntansi tetapi Non Akuntansi.

\section{REFERENSI}

Akerlof, R. (2006). A Theory of Social Motivation. Unpublished Manuscript: Cambribge, $M A$.

Ayuningtyas, N. dan F. N. P. (2012). Faktor- Faktor Yang Mempengaruhi Minat Mahasiswa Akuntansi Untuk Mengikuti Penddikan Profesi Akuntansi (PPAk). Juraksi, 1(1).

Akerlof, Robert J. 2006. A Theory of Social Motivation.Unpublished Manuscript: Cambribge, MA.

Ayu Dewi Vesparalis. 2017 Pengaruh Motivasi Pada Minat Sarjana Akuntansi Universitas Udayana Mengikuti PPAk, E-Jurnal Akuntansi Universitas Udayana, 19 (2), hal.1691-1718.

Ayuningtyas, Novika dan Febrina Nafasati Prihatini. (2012). Faktor- Faktor Yang Mempengaruhi Minat Mahasiswa Akuntansi Untuk Mengikuti Penddikan Profesi Akuntansi (PPAk).Juraksi, 1 (1).

Benny, E. dan Y. (2006). Pengaruh Motivasi Terhadap Minat Mahasiswa Akuntansi Untuk Mengikuti Pendidikan Profesi Akuntansi Untuk Mengikuti Pendidkan Profesi Akuntansi (Studi Empiris Pada Perguruan Tinggi di Padang). Simposium Nasional Akuntansi Padang., Padang: Universitas Andalas.

Buss, D. M., \& Inquiry, P. (1997). Human social motivation in evolutionary perspective: Grounding terror management theory. Psychological Inquiry, 8(1), 22-26. Retrieved from

Chevallier, C., Grèzes, J., Molesworth, C., Berthoz, S., \& Happé, F. (2012). Brief report: Selective social anhedonia in high functioning autism. Journal of Autism and Developmental Disorders, 42(7), 1504-1509. https://doi.org/10.1007/s10803-011-1364-0

Coralie, Chevalier, Jule, Grezes. Chatrine, M. (2012). Brief report: Selective Social Anhedonia in High Function Autism. Journal of Austim and Developmental Disorders, 42(7), pp: 1504-1509

Dewi, I. F., \& Setiawanta, Y. (2008). Pengaruh Persepsi Dan Motivasi Mahasiswa Jurusan Akuntansi Yang Sedang Mengambil Skripsi Terhadap Peminatan Karir Dalam Bidang PERPAJAKAN (Studi Empiris Pada Mahasiwa Akuntansi Universitas Dian Nuswantoro).

Farmer, H. S. (1976). What Inhibits Achievement and Career Motivation in Women? The Counseling Psychologist, 6(2), 12-15. https://doi.org/10.1177/001100007600600204

Frank, H. K. (1940). Professor Parsons on Economic Motivation. Canadian Journal of Economics and Political Sciene. 6(3), pp: 460-465.

Indonesia, M. P. dan K. R. (2014). Peraturan Menteri Pendidikan dan Kebudayaan Republik Indonesia Tentang Penyelenggaraan Pendidikan Program Profesi Akuntan Nomor 153. 
Istina, Dewi dan Yulita.(2008). Pengaruh Persepsi dan Motivasi Mahasiswa Jurusan Akuntansi yang Sedang Mengambil Skripsi Terhadap Permintaan Karir Dalam Bidang Perpajakan (Studi Empiris pada Mahasiswa Akuntansi Universitas Dian Nuswantoro). Skiripsi Fakultas Ekonomi Universitas Dian Nuswantoro.

Jensen, C., \& Meckling, H. (1976). Theory of the Firm: Managerial Behavior Agency Cost, and Ownership Structure. Journal of Financial Economics, 3, 305-360. https:/ / doi.org/10.1016/0304-405X(76)90026-X

Joseph Sirgy, M., Gurel-Atay, E., Webb, D., Cicic, M., Husic-Mehmedovic, M., Ekici, A., ... Johar, J. S. (2013). Is Materialism All That Bad? Effects on Satisfaction with Material Life, Life Satisfaction, and Economic Motivation. Social Indicators Research, 110(1), 349-366.https://doi.org/10.1007/s11205011-9934-2

Kermis, G. (2011). Professional presence and soft skills: a role for accounting education. Journal of Instructional Pedagogies, 2, 1-10.

Kusumastuti, R., \& Waluyo, I. (2013). Pengaruh Motivasi Dan Pengetahuan Uu No.5 Tahun 2011 Tentang Akuntan Publik Terhadap Minat Mahasiswa Akuntansi Mengikuti Pendidikan Profesi Akuntansi (Ppak). Nominal, Barometer Riset Akuntansi Dan Manajemen, 2(2), 1-30. https://doi.org/10.21831/nominal.v2i2.1662

Lisnasari, R. N. dan F. (2008). Faktor-Faktor Yang Mempengaruhi Minat Mahasiswa Akuntansi Untuk Mengikuti Pendidikan Profesi Akuntansi (PPA). Dalam Accounting Conference II, Jakarta: FEUI.

London, M. (1983). Toward a theory of career motivation. Academy of Management Review, 8(4), 620-630.

Lisnasari, Riani Nurainah dan Fitriany. 2008. Faktor-Faktor Yang Mempengaruhi Minat Mahasiswa Akuntansi Untuk Mengikuti Pendidikan Profesi Akuntansi (PPA).Dalam Accounting Conference II. Jakarta: FEUI

McClelland. (1987). The Achieving Society, New York: A Divison of Macmillan Publishing Co.,. https:/ / doi.org/10.1108/13552550510590554

McClintock, C. G. (1972). Social Motivation- A set of propotions. Behavioral Sciene,. 17(5), 438-454.

McCormick, E. J. (1985). Industrial Psychology. European Journal of Social Psychology, York: Frentice-Hall, Inc. https://doi.org/10.1002/ ejsp.2420140302

Nisa, N. A. K. (2012). Faktor - Faktor Yang Mempengaruhi MinatMahasiswa Untuk Mengikuti Pendidikan Profesi Akuntansi (PPAk) DiSurakarta (Survai Pada Perguruan Tinggi Di Surakarta). Skripsi, Fakultas Ekomomi Universitas Muhammadiyah Surakart.

Noe, R. A., Noe, A. W., \& Bachhuber, J. A. (1980). An investigation of the correlates of career motivation. Journal of Vocational Behavior, 37(3), 340-356.

Nurhayani, U. (2012). Pengaruh Motivasi Terhadap Minat Mahasiswa untuk Mengikuti Pendidikan Profesi Akuntansi (PPAk) (Studi Empiris pada Perguruan Tinggi Swasta Medan). Juraksi Mediasi, 4(10), 59-67.

Peraturan Menteri Keuangan Republik Indonesia Nomer 25/PMK.01/2014.Tentang akuntan beregister Negara. 
Peraturan Menteri Pendidikan dan Kebudayaan Republik Indonesia Nomor 153 Tahun 2014.Tentang Penyelenggaraan Pendidikan Program Profesi Akuntan.

Peraturan Ikatan Akuntansi Indonesia Nomor 2 tahun 2015.Tentang Mekanisme pelaksanaan ujian Chartered Accountant Indonesia bagi mahasiswa pendidik program profesi akuntan.

Paisey, C. dan N. J. P. (2005). Cutting the Core A Reflection Upon Recent Education Policy Debates Within the Institute of Chartered Accountants in England and Wales. The British Accounting Review, 38(1), pp: 31-61.

Purnamasari, K. (2014). Peran motivasi dalam mempengaruhi minat mahasiswa mengikuti ppa.

Rita, Kusumastuti. Indarto, Waluyo. (2013). Pengaruh Motivasi dan Pengetahuan UU No.5 Tahun 2011 Tentang Akuntan Publik Terhadap Minat Mahasiswa Akuntansi Mengikuti Pendidikan Profesi Akuntansi.Jurnal Nominal, 2 (2).

Suwardjono. (2012). Teori Akuntansi: Perekayasaan Pelaporan Keuangan. Edisi Ketiga. Yogyakarta: BPFE.

Tracey Mc, D. and B. J. (2010). What Influances Accounting Students' Attitude Towards Accounting As a Profession? Journal of Accounting Perception: Conference Proceedings, AFAANZ.

Vesparalis, A. D. (2017). Pengaruh Motivasi Pada Minat Sarjana Akuntansi Universitas Udayana Mengikuti PPAk. E-Jurnal Akuntansi Universitas Udayana, 19(2), hal.1691-1718.

Widyasari, Y. (2010). Persepsi Mahasiswa Akuntansi Mengenai Faktor-Faktor Yang Membedakan Pemilihan Karir (Studi Pada Universitas Diponegoro Dan Unika Soegijapranata)

Widyastuti, S. dan J. (2004). Pengaruh Motivasi Terhadap Minat Mahasisiwa Akuntansi Untuk Mengikuti Pendidikan Profesi Akuntansi. Simposium Nasional Akuntansi VII, Denpasar.

Weygant, Donald E. Keiso and Paul D. 1996. Auditor Liability in The UK: The Case for Reform. Critical Perspective on Accounting and Auditing, 10 (3) 